ISSN: 2224-0616

Int. J. Agril. Res. Innov. Tech. 11(1): 49-59, June 2021

DOI: https://doi.org/10.3329/ijarit.v11i1.54466
OPEN $\%$ ACCESS

Available online at https://ijarit.webs.com https://www.banglajol.info/index.php/IJARIT

\title{
Adaptation of agroforestry as a climate smart agriculture technology in Bangladesh
}

\author{
Z.A. Riyadh' ${ }^{1}$ M.A. Rahman ${ }^{1,2}{ }^{*}$, S.R. Saha ${ }^{1}$, T. Ahamed $^{1}$ and D. Current ${ }^{3}$ \\ Received 10 March 2021, Revised 31 May 2021, Accepted 23 June 2021, Published online 30 June 2021
}

\begin{abstract}
A B S T R A C T
Geographical position makes Bangladesh globally as one of the most vulnerable countries to climate change. It is observed that climate change has become a burning issue jeopardizing the agricultural production in the country. Considering the issue, adoption of climate smart agriculture (CSA) is indispensable for mitigating climate change by reducing emissions, capturing the atmospheric carbon and storing it in biomass and soil. The study reviewed the literature to evaluate the potentiality of agroforestry practices as climate smart agriculture to mitigate climate change impacts. Agroforestry has traditionally contributed to climate resilience in Bangladesh by integrating trees and/or crops into different land use practices. Agroforestry systems enhance resilience to climate change through increasing tree cover, carbon sequestration, increasing production, reducing threats to associated crops, creating favourable microclimate to support associated crops, reducing harvest pressure on natural forests, conserving biodiversity and cycling nutrients. Globally 23 countries recognize agroforestry as a mitigation priority, whereas 29 as an adaptation priority. Bangladesh has potential to expand agroforestry practices to mitigate climate change and boost food security. From socioeconomic and ecological point of views as well, agroforestry offers strong potential to evolve climate smart agricultural practices supporting food security, and adaptation and mitigation. Agroforestry practices should increase in climate vulnerable agroecosystems of Bangladesh.
\end{abstract}

Keywords: Climate change, Agroforestry, Adaptation, Carbon sequestration, Mitigation.

${ }^{1}$ Department of Agroforestry and Environment, Bangabandhu Sheikh Mujibur Rahman Agricultural University, Gazipur1706, Bangladesh.

${ }^{2}$ World Agroforestry (ICRAF), South Asia Regional Program, New Delhi, India.

${ }^{3}$ Department of Forest Resources, University of Minnesota, Saint Paul, Minnesota 55108-6112, USA.

*Corresponding author's email: abiar@bsmrau.edu.bd (M.A. Rahman)

Cite this article as: Riyadh, Z.A., Rahman, M.A., Saha, S.R., Ahamed, T. and Current, D. 2021. Adaptation of agroforestry as a climate smart agriculture technology in Bangladesh. Int. J. Agril. Res. Innov. Tech. 11(1): 4959. https://doi.org/10.3329/ijarit.v11i1.54466

\section{Introduction}

Climate is the precious physical condition of an area for crop production. Climatic variables are important environmental factors that condition ecological niches of plant species and their patterns of distribution (Trisurat et al., 2009). Climate change is a global challenge to sustainable crop production and global food security (Rahman et al., 2018; Elahi and Khan, 2015). Rural livelihoods and economic development of Bangladesh largely depend on agriculture, which apart from climate change, is also under pressure due to limited land availability (Uthappa et al., 2017).

Geographically, Bangladesh is located on an active delta, which is highly exposed to different climatic hazards and natural disasters (Hanif et al., 2015), and is globally ranked as the sixth most climate vulnerable country (Kreft et al., 2017). Approximately $41 \%$ of the country's total land is under climate change risk (Mandal, 2016). The agricultural sector is extremely vulnerable to increasing mean ambient temperature, changing rainfall patterns and rise of sea level. Almost every year, the country faces tropical cyclones, floods, storm surge, riverbank and coastal erosion as well as drought affecting agricultural activities (Mutahara et al., 2017; Dastagir, 2015), and these extreme events are expected to increase in future (Minar et al., 2013; Dastagir, 2015; Sikder and Xiaoying, 2014). To mitigate the effects of extreme weather conditions, it is necessary to increase coping capacity through adoption of climate smart technologies (Rijal, 2019). 
Climate change negatively affects ecological systems and human livelihoods, increases vulnerability and therefore needs technologies for adaptation (IPCC, 2014). According to the United Nations Framework Convention on Climate Change, adaptation technology is the application of technology in order to reduce the vulnerability, or enhance the resilience of a natural or human system to the impacts of climate change (UNFCCC, 2010). Enhanced technology adaptation is globally recognized as a significant strategy to reduce the negative impacts of climate change.

For climate change mitigation, adoption of climate smart agriculture technologies is very effective. The Food and Agriculture Organization (FAO) of the United Nations defines CSA as "agriculture that sustainably increases productivity, enhances resilience (adaptation), reduces/removes GHGs (mitigation) where possible, and enhances achievement of national food security and development goals" (FAO, 2010). It aims to ensure food security and wide development goals under the climate change scenario and increasing food demand (World Bank, 2017). The CSA practices have potential to reverse the climate changing trend due to its triple potential benefits of improved productivity and high income, reduction or removal of greenhouse gases (GHGs) and improved household food security (Wekesa et al., 2018). Moreover, CSA can strengthen farmer's livelihoods and increase carbon sequestration by creating carbon sinks, and reducing GHGs emissions from agricultural sectors (Raj et al., 2018).

Agroforestry systems are well recognized as an integrated practice for sustainable land use beside their contribution to climate change mitigation and adaptation (Cubbage et al., 2013; Verma et al., 2014; Schoreneberger et al., 2012; Colin, 2013). Agroforestry is the intentional and integrated management of agriculture and forestry principles to create diverse, profitable, productive, and sustainable land use systems (Rietveld, 1995). Linkages between agroforestry and CSA promote aspects related to soil health, resource distribution, carbon sequestration, biodiversity, water management and food security (Newaj et al., 2015). Adaptation and use of agroforestry affect climate change by increasing the tree cover outside forests, increasing carbon sequestration, enhancing forest carbon stocks, reducing risks, conserving biodiversity, maintaining soil health, and scaling up multiple benefits (De Zoysa and Inoue, 2014). Carbon sequestration is one of the most important strategies that could mitigate the consequences of climate change to some extent by incorporating atmospheric $\mathrm{CO}_{2}$ into the longlived natural pools such as soils and green biomass (Lorenz and Lal, 2014; Srinivasarao, 2017). Both carbon sequestration and CSA are interdependent and different practices of CSA that include agroforestry have the ability to build carbon accumulation in plants and soils, and facilitate food security (Raj et al., 2018). Owing to its high potential for building resilience to climate change, sequestering carbon, and strengthening rural livelihoods, agroforestry is one of the most effective components of CSA (Colin, 2013).

Twenty-three countries recognize agroforestry as a mitigation priority, whereas 29 as an adaptation priority (CGIAR, 2017), but there is lack of information on potential role of agroforestry as CSA in Bangladesh. Moreover, there is very limited data on carbon sequestration of agroforestry systems in the country. Therefore, this paper reviews the available literature with a view to explore the effects of climate change on agriculture and vice versa, and to describe the opportunities of the adaptation of agroforestry for climate change mitigation in Bangladesh.

\section{Contribution of agriculture to climate change}

Agricultural land use has a notable contribution to greenhouse gases (GHGs) emissions and is responsible for $25 \%$ of total anthropogenic emissions (UNFAO, 2014). Studies have anticipated that intensive agricultural practices have detrimental effects on the environment (Gurung and Temphel, 2015). Agriculture contributes to GHGs emission through crop cultivation (production of nitrogen-based fertilizers, the combustion of fossil fuels etc.) and livestock rearing, as well as through land use change from forest to cropland. Nitrous oxides and methane are the major GHGs; and globally, the agriculture sector contributes $58 \%$ of nitrous oxide and $54 \%$ of anthropogenic methane emissions (Pal et al., 2019).

The agricultural sector of Bangladesh contributes about 53.78 million tons of GHGs every year, and the major sources of GHGs emission from agricultural sector is rice cultivation (24.63 million tons) and enteric fermentation (24.23 million tons) (Fig. 1a). Cropland agriculture and livestock production contributed equally to agricultural emissions in 2013 (Fig. 1b). Agricultural activities contribute $39 \%$ of the country's total GHG emissions (World Bank, 2017). In this context, conserving the environment and making agricultural practices less harmful to the environment are challenges to food production. 


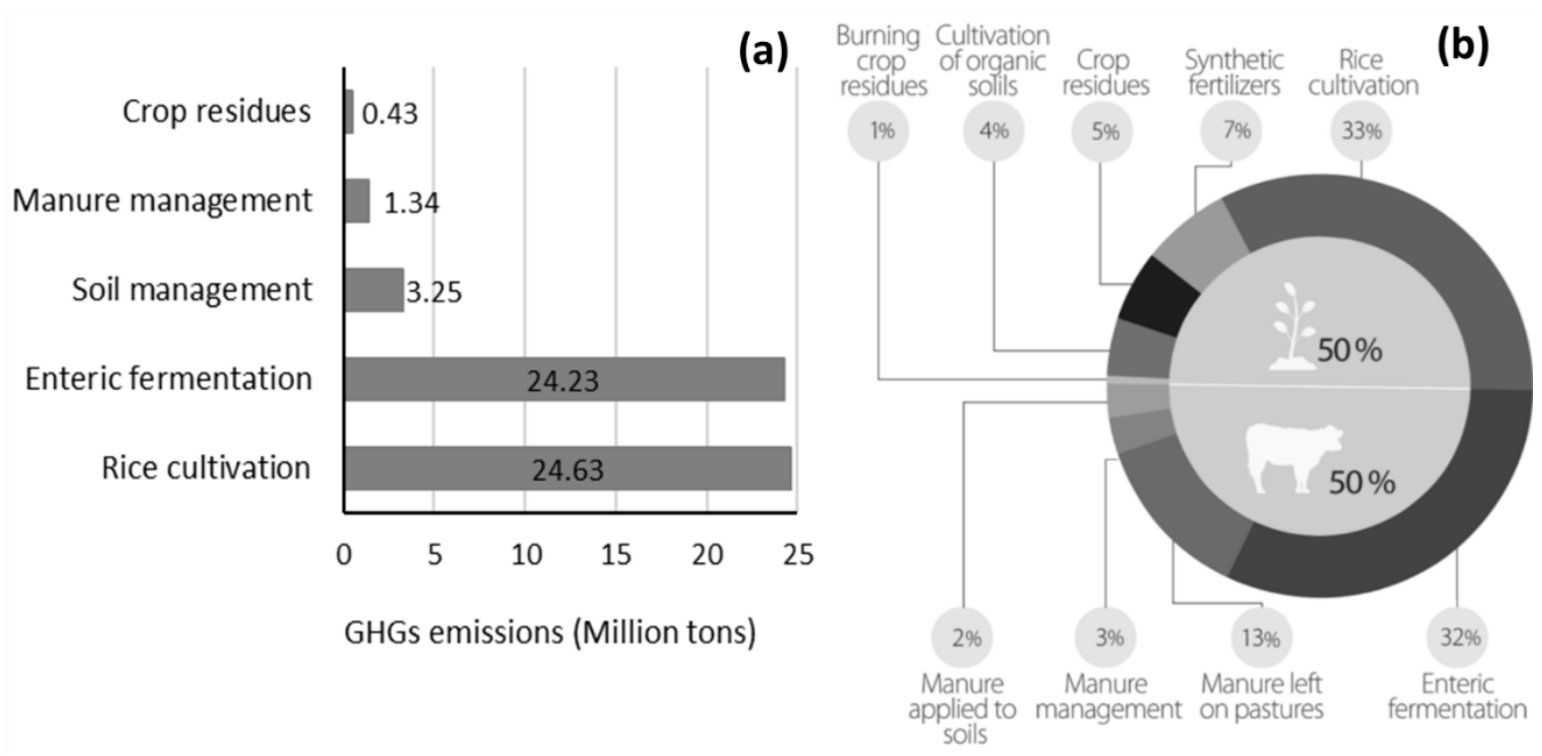

Fig. 1. (a) Amount of agricultural GHGs emission (Pal et al., 2019), and (b) emissions percent of different agricultural activities in Bangladesh (World Bank, 2017).

\section{Impacts of climate change on agriculture}

Field agriculture is the most vulnerable sector as its productivity totally depends on climatic conditions like temperature, rainfall, humidity etc. Farming has been threatened by the complexity and magnitude of climate change induced extreme events. Bangladesh is one of the most vulnerable countries in the world to climate change due to geographic exposure, low income and a greater reliance on the climate sensitive agriculture sector (Rahaman et al., 2019; Mandal, 2016). Climate change in Bangladesh has a negative impact on agricultural production as well as food security. The effect of climate change on crop production is already evident in several eco-sensitive zones like coastal areas, drought and flood prone areas of the country (Hoque and Haque, 2016). According to the Intergovernmental Panel on Climate Change, about $8 \%$ and $32 \%$ production of rice and wheat, respectively, in Bangladesh could decrease by 2050, compared to a base year 1990, which could lead to serious food insecurity (IPCC, 2014).

\section{Agroforestry potentials as CSA technology}

Agroforestry is receiving immense attention not only in terms of sustainable agriculture but also as an effective tool to deal with climate change (Saikia et al., 2017; Hanif et al., 2015; Rijal, 2019). In crop agriculture, CSA practices and technologies are broadly included in crop management, soil management, water management, agroforestry and energy management (Mahashin and Roy, 2017). Agroforestry systems involve land management practices, perennial crops, long rotation systems for soil conservation including crop diversification, home gardens, boundary plantings, hedgerow intercropping, live fences, improved fallows, multistorey agroforestry etc. (Uthappa et al., 2017).

Agroforestry systems reduce the effects of climate change by providing multiple products, increasing tree cover outside forests, facilitating biodiversity, enhancing forest carbon stocks, increasing carbon sequestration, reducing risks and damage intensity to farmland (Table 1 ). Trees on agro-farm perform production, protection (biological and physical) and regulation (nutrient cycle, hydrological cycle, and carbon sequestration) functions (Rijal, 2019). Trees planted on only $3-5 \%$ of agricultural lands can increase farm productivity, reduce vulnerability to climate change and greenhouse gas emissions (Possu et al., 2016). Tree-based farming systems reduce greenhouse gas emissions from soils, increase carbon stocks and are considered as a cost-effective strategy for climate change mitigation (Verchot et al., 2007; Goswami et al., 2014; Smith and Olesen, 2010). 
Table 1. Contributions of agroforestry as climate smart agriculture (Schoreneberger et al., 2012; Mahashin and Roy, 2017).

\begin{tabular}{|c|c|c|c|}
\hline $\begin{array}{l}\text { Pillars of } \\
\text { CSA }\end{array}$ & $\begin{array}{l}\text { Climate Change } \\
\text { Strategy }\end{array}$ & Key functions & Agroforestry role \\
\hline Productivity & $\begin{array}{l}\text { Practices that } \\
\text { increase food } \\
\text { production and } \\
\text { security }\end{array}$ & $\begin{array}{l}\text { Increase farm } \\
\text { production } \\
\text { through } \\
\text { sustainable } \\
\text { land use }\end{array}$ & $\begin{array}{l}\text { Agroforestry provides diversified products } \\
\text { (food, wood, fuel, fodder etc.) with } \\
\text { continuous flow of supply and higher } \\
\text { income, various ecosystem services like } \\
\text { microclimatic modification, improves soil } \\
\text { quality, etc. that increases productivity. }\end{array}$ \\
\hline Adaptation & $\begin{array}{l}\text { Action to reduce } \\
\text { negative effects of } \\
\text { climate changes } \\
\text { and/or take } \\
\text { advantage of the } \\
\text { positive effects }\end{array}$ & $\begin{array}{l}\text { Reduce } \\
\text { threats and } \\
\text { enhance } \\
\text { resilience }\end{array}$ & $\begin{array}{l}\text { Agroforestry reduces the impact of extreme } \\
\text { weather events on crop production as } \\
\text { shelterbelts and windbreaks, increase the } \\
\text { absorptive capability of soil and decrease } \\
\text { evapotranspiration, provide greater habitat } \\
\text { diversity to support organisms (useful } \\
\text { insects, native pollinators and birds), } \\
\text { reduces the pressure on natural forests thus } \\
\text { maintain and protect natural resources. }\end{array}$ \\
\hline Mitigation & $\begin{array}{l}\text { Activities that } \\
\text { reduce emission of } \\
\text { GHGs in the } \\
\text { atmosphere or } \\
\text { increase the storage } \\
\text { of GHGs in } \\
\text { ecosystems }\end{array}$ & $\begin{array}{l}\text { Enhance } \\
\text { carbon } \\
\text { sequestration } \\
\text { and reduce } \\
\text { GHGs } \\
\text { emission }\end{array}$ & $\begin{array}{l}\text { Agroforestry increases tree cover outside } \\
\text { forests thus enhance the accumulation of } \\
\text { carbon in both tree biomass and soil, } \\
\text { conserve existing carbon stock of the } \\
\text { forests through providing alternate source } \\
\text { of fuel, fodder and timber, reduce } \\
\text { deforestation and land degradation, } \\
\text { enhance forage quality and thereby } \\
\text { reducing } \mathrm{CH}_{4} \text { emission. } \\
\text { Reduce } \mathrm{N}_{2} \mathrm{O} \text { emission by greater nutrients } \\
\text { uptake through trees. }\end{array}$ \\
\hline
\end{tabular}

Agroforestry systems play a vital role in controlling soil erosion mainly through interception, infiltration etc. Agroforestry practice as contour hedgerows on steep hill slopes (40-50\%) can reduce runoff by $30-70 \%$ and soil erosion by $55-80 \%$ compared to traditional shifting cultivation (Khisa, 2001). Farmers of Bangladesh are trying to develop coping mechanisms against climate change oriented natural hazards like droughts, more severe floods, greater rainfall variability, tidalsurges, salinity etc. through practicing different technologies. Bangladesh has a wide range of agro-ecological zones (AEZ) and farmers have been practicing tree growing in crop fields of different AEZ for centuries. Agroforestry is reported as a popular climate resilient technology and practiced by $39.4 \%$ of the surveyed farmers in Chilmari upazila (a flood and riverbank erosion affected area) of Kurigram and, $6.7 \%$ of farmers in Khaliajuri upazila (a flash flood and highly hailstorm affected area) of Netrokona districts (Rahaman et al., 2019). A study on CSA technologies for sustainable crop production revealed that $60 \%$ of the studied farmers practiced agroforestry as CSA technology in the coastal region of Bangladesh (Billah and Hossain, 2017).
Unfortunately, there is no intensive study on agroforestry as CSA practices and technologies in Bangladesh. Most of the agroforestry studies in the country focused on its potential to improve crop production and food and livelihood security, for microclimatic modification, for soil fertility management, and ecological aspects. Globally, at least 70 countries have recognized agroforestry as one of the vital tools to adopt for climate change mitigation (Richards et al., 2016). Strengthening adaptation mechanisms of sustainable agroforestry management by combining agriculture and forestry reduces the effects of climate change (De Zoysa and Inoue, 2014).

\section{Multiple benefits of agroforestry}

Agroforestry, a multifunctional farming system, provides crops, fruit, timber, fuel, fodder, medicine and ecosystem services. Agroforestry systems increase total farm production and household income thereby improving the livelihood status of rural farmers (Fig. 2). Fruit tree-based agroforestry systems in Bangladesh provide higher net return and land equivalent ratio than a comparable sole cropping system without trees (Riyadh et al., 2020; Miah et al., 2018; Hossain et al., 2014). Growing food producing trees in agroforestry systems increases the nutritional and economic security of subsistence farmers living in tropical countries (World Bank, 2006). 


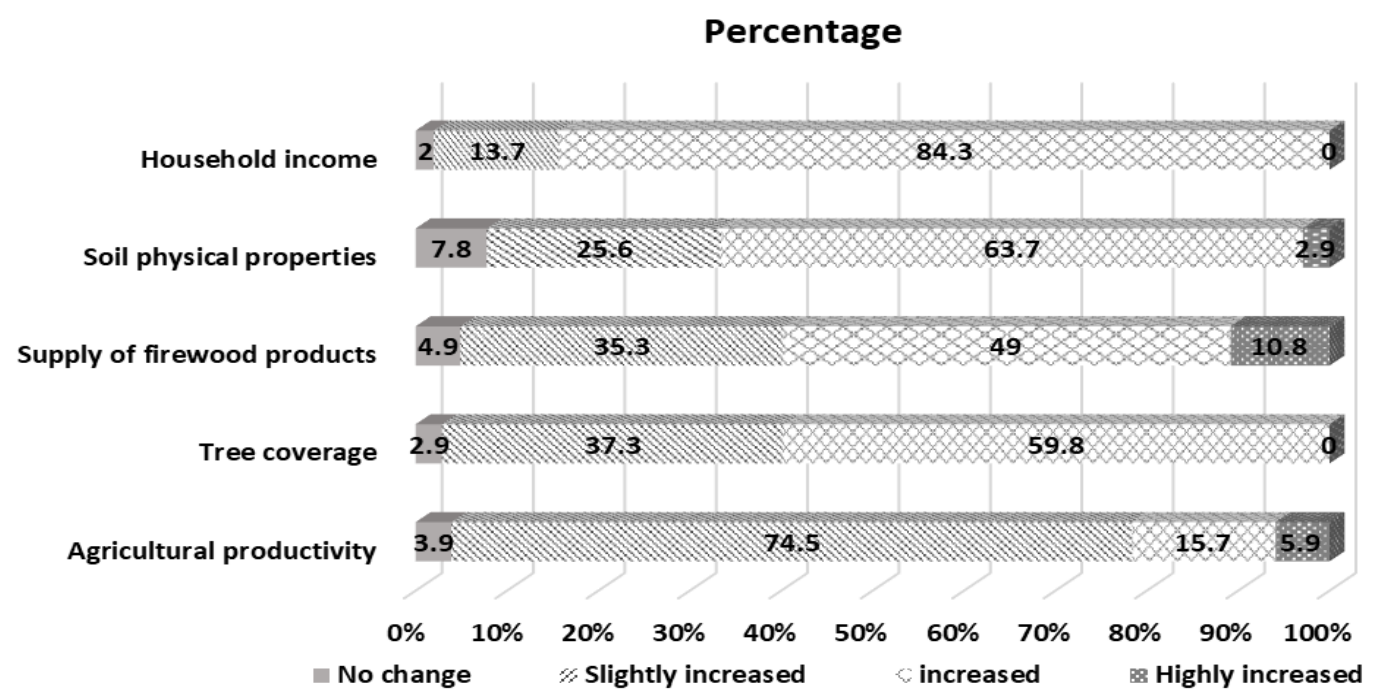

Fig. 2. Distribution of farmers on assessment of livelihood potentials of agroforestry (Hanif et al., 2018).

Nitrogen fixing trees in agroforestry systems improve soil fertility through fixing atmospheric $\mathrm{N}$ in soil and thus enhance the production of the systems. Agroforestry systems increase soil organic matter, total nitrogen and soil moisture content (Dollinger and Jose, 2018; Miah et al., 2018; Riyadh et al., 2018; Rahman et al., 2009). Agroforestry systems have been found suitable for preventing soil erosion in Chittagong Hill Tracts of Bangladesh (Hossain et al., 2020). Nowadays, agroforestry is one of the cropping practices with the greatest potential for maintaining soil health. The role of agroforestry in maintaining soil health is demonstrated in Fig. 3. Planting trees in agroforestry systems in Bangladesh is also recognized as an alternative strategy to supply wood and fuel in order to fulfill household and market demands. Homestead agroforestry as a potential land use system in Bangladesh provides opportunities for increasing community forests in addition to other benefits.

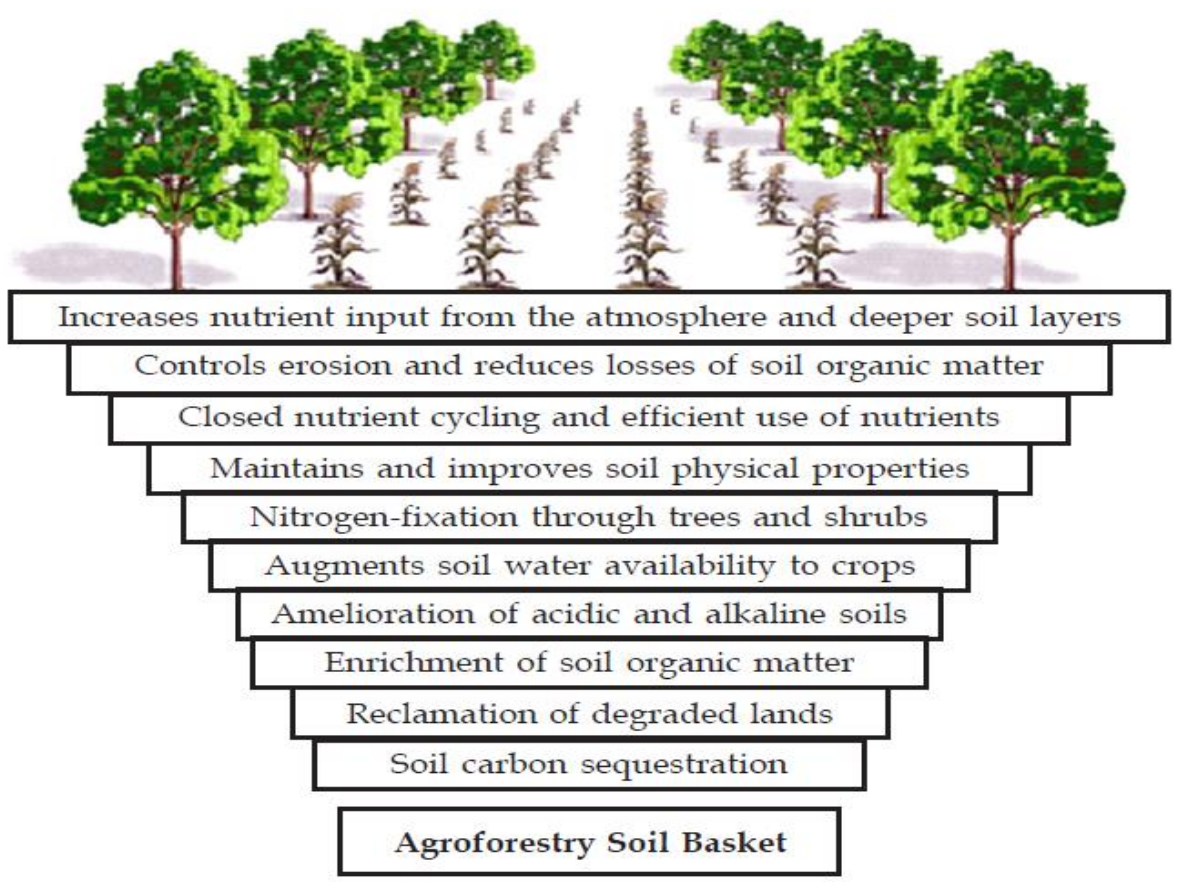

Fig. 3. Maintaining soil health through agroforestry (Uthappa et al., 2015).

Microclimatic modification through agroforestry has an outstanding effect on crop production as trees can buffer environmental extremes that affect crop growth (Uthappa et al., 2017). The shading effects of trees in agroforestry systems can buffer both air and soil temperature along with relative humidity. The beneficial effects of microclimatic modification are noticed in agroforestry as shade created by trees protects heat sensitive crops from high temperatures 
(Uthappa et al., 2017). Windbreaks and shelterbelts are also the most important ways to reduce physical damage to crops during cyclones and storms and slow down the wind speed reducing evaporation from crops and soils.

\section{Carbon sequestration potentials of agroforestry}

Increasing carbon sequestration capacity of agricultural land is an important emission reduction pathway. Carbon sequestration includes the removal and storage of atmospheric carbon in different carbon sinks like vegetation, soils and oceans through biological or physical processes (Jose, 2009). Carbon sequestration in the terrestrial ecosystem includes both the aboveground and belowground plant biomass, and the relatively stable forms of organic and inorganic carbon in the soil profile (Dhyani et al., 2020). Agroforestry systems have the ability to increase soil carbon stocks in agricultural lands thus potentially helping farmers to adopt climate change mitigation options and improve soil health (Ghosh et al., 2020; Verchot et al., 2007; Luedeling et al., 2011). The Kyoto Protocol suggested that agroforestry practice is an important potential approach for mitigating atmospheric $\mathrm{CO}_{2}$. Globally, there is increasing evidence that agroforestry systems are promising agricultural management practices for increasing above ground and soil carbon stocks to mitigate GHGs and the impacts of climate change (Srinivasarao et al., 2020).
A substantial increase in the area under agroforestry will have a significant impact on the flux and long-term carbon storage in the terrestrial biosphere (De Zoysa and Inoue, 2014). The amount of carbon sequestration in agroforestry system is much higher than in monoculture crop fields (land use without tree) or pasture (Murthy et al., 2013, Verchot et al., 2007). It is estimated that the area under agroforestry in the world is $8.2 \%$ of the total geographical area (305.6 million ha) and it contributes $19.3 \%(2755.5 \mathrm{mt} \mathrm{C})$ of the total carbon stock (Uthappa et al., 2017). An estimation of the carbon sequestration capacity of tropical agroforestry systems ranged from 12-228 $\mathrm{Mg} \mathrm{ha}^{-1}$ with an average of $95 \mathrm{Mg} \mathrm{ha}^{-1}$ (Newaj and Dhyani, 2008). The carbon sequestration efficiency of an agroforestry system is $0.35 \mathrm{Mg}$

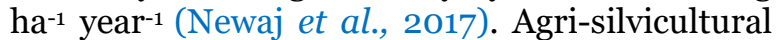
systems have the capability for storing carbon 68$81 \mathrm{Mg} \mathrm{ha}^{-1}$ in dry lowlands and 12-228 $\mathrm{Mg} \mathrm{ha}^{-1}$ in humid tropical lands of Southeast Asia (Murthy et al., 2013). The report anticipated that about 630 million ha of grasslands and unproductive croplands could be modified into agroforestry systems by 2040 representing a carbon sequestration potential of 586,000 $\mathrm{Mg}$ year $^{-1}$ (Jose, 2009). The IPCC (2000) estimated the capacities of global carbon sequestration of various land use systems and reported that agroforestry systems have the highest capability (40.96\% of total land use carbon stock) (Table 2).

Table 2. Carbon sequestration potential of different land use systems by 2040 (IPCC, 2000).

\begin{tabular}{|lcc|} 
Carbon Sequestration Sinks & Mt C year-1 & Percent (\%) \\
\hline Agroforestry & 600 & 40.96 \\
\hline Grazing management & 375 & 25.60 \\
\hline Forest management & 250 & 17.06 \\
\hline Cropland management & 150 & 10.24 \\
\hline Restoration of degraded lands & 50 & 3.41 \\
\hline Rice management & 20 & 1.37 \\
\hline Wetland restoration & 20 & 1.37 \\
\hline Total & 1465 & 100 \\
\hline
\end{tabular}

Total biomass carbon and soil organic carbon (top $20 \mathrm{~cm}$ depth of soil) in different agroforestry systems of Bangladesh are given in Table 3. The highest biomass carbon (134.44 $\mathrm{Mg} \mathrm{ha}^{-1}$ ) and soil organic carbon (30.36 $\mathrm{Mg} \mathrm{ha}^{-1}$ ) were in betel-vine agroforestry among four agroforestry systems due to the higher tree density of the system. However, the carbon sequestration efficiency of agroforestry varied depending on different factors including land use systems, tree and crop species, age and frequency of tree species, region, soil quality etc. Carbon sequestration potentials of three important agroforestry tree species from the northern region of Bangladesh are presented in Table 4. The quantity of total carbon stock in agroforestry systems notably varied in different ecosystems (Fig. 4). The highest amount of total carbon was found in the terrace ecosystem (207.60 ton ha $\mathrm{h}^{-1}$ ) followed by the barind tract (174.62 ton ha $\mathrm{ha}^{-1}$ ) and the lowest in hill tracts (155.42 ton ha $^{-1}$ ). This variation might be due to tree species and number of trees in the agroforestry system and soil carbon stock. However, it is worthy to mention that the efficiency of carbon sequestration of agroforestry systems must be examined intensively in Bangladesh. 
Table 3. Biomass and soil carbon in different agroforestry systems (Mukul, 2014).

\begin{tabular}{|lccc|}
\hline Agroforestry Land Use & $\begin{array}{c}\text { No. of tree } \\
\text { ha-1 }\end{array}$ & $\begin{array}{c}\text { Total Biomass } \\
\text { Carbon }\left(\mathrm{Mg} \mathrm{ha}^{-1}\right)\end{array}$ & $\begin{array}{c}\text { Soil Organic } \\
\text { Carbon }\left(\mathrm{Mg} \mathrm{ha}^{-1}\right)\end{array}$ \\
\hline Lemon based agroforestry & 740 & 47.89 & 23.08 \\
\hline Pineapple agroforestry & 330 & 5.97 & 19.94 \\
\hline Betel-vine agroforestry & 1670 & 134.44 & 30.36 \\
\hline Shifting cultivation & 680 & 9.57 & 29.05 \\
\hline
\end{tabular}

Table 4. Carbon sequestration potentials of three common agroforestry species at the age of $5-7^{\text {th }}$ year after plantation in Bangladesh (Hanif et al., 2015).

\begin{tabular}{|lcccccc|}
\hline \multirow{2}{*}{ Agroforestry species } & \multicolumn{3}{c}{$\mathrm{CO}_{2} \mathrm{~T}^{-1} \mathrm{Y}^{-1}(\mathrm{Kg})$} & \multicolumn{3}{c|}{$\mathrm{CO}_{2} \mathrm{ha}^{-1} \mathrm{Y}^{-1}(\mathrm{Mg})$} \\
Leucaena leucocephala & $5^{\text {th }}$ year & $6^{\text {th }}$ year & $7^{\text {th }}$ year & $5^{\text {th }}$ year & $6^{\text {th }}$ year & $7^{\text {th }}$ year \\
\hline Melia azedarach & $72.00 \mathrm{a}$ & $88.70 \mathrm{a}$ & $123.7 \mathrm{a}$ & $76.07 \mathrm{ab}$ & $96.86 \mathrm{a}$ & $135 \mathrm{a}$ \\
\hline Albizia lebbeck & $61.53 \mathrm{~b}$ & $78.48 \mathrm{~b}$ & $109.9 \mathrm{~b}$ & $78.62 \mathrm{a}$ & $97.16 \mathrm{a}$ & $120 \mathrm{~b}$ \\
\hline CV $(\%)$ & 5.73 & 0.75 & 0.78 & $67.19 \mathrm{~b}$ & $85.70 \mathrm{~b}$ & $115 \mathrm{~b}$ \\
\hline
\end{tabular}

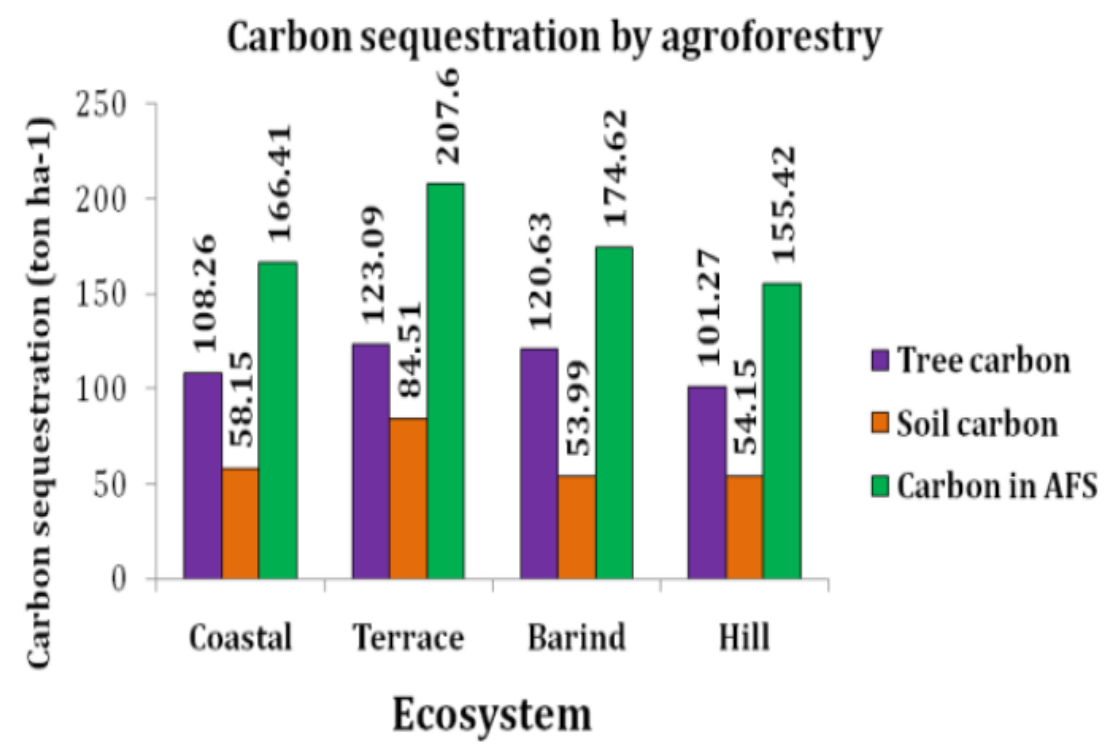

Fig. 4. Total carbon stock by agroforestry systems in different ecosystems (Talukder et al., 2019).

\section{Scope for expansion of agroforestry in Bangladesh}

Recently, commercial orchards of different fruits (mango, guava, orange, jujube, litchi and lemon) are increasing in different agroecological zones of Bangladesh. These fruit orchards offer significant opportunities for conversion into agroforestry systems. In the drought prone north and northwestern regions of Bangladesh, planted crops in fruit orchards represents a well-managed and profitable activity. Rapidly growing Eucalyptus and Acacia trees could be planted in croplands of the northwestern region, an area of Bangladesh devoid of natural forest. Subsistence livelihoods could be supported by adopting a well-managed homestead agroforestry system.
More than 20 million homesteads represent a well-established land use system and represent one possible means of biodiversity conservation in Bangladesh (Kabir and Webb, 2008). Homestead agroforestry also provides different ecosystem services such as soil conservation, carbon sequestration, preserving of water and air quality (Peichl et al., 2006). Hence, it is regarded as climate smart agricultural practice. However, different agroforestry systems may be better adapted for specific regions of Bangladesh, as demonstrated in Table 5. Agroforestry practices could also be successfully applied in the buffer areas of degraded Sal forests, contributing to the mitigation of climate change. 
Table 5. Agroforestry systems to address climate change effects for different regions of Bangladesh.

\begin{tabular}{|c|c|c|}
\hline Agroforestry Systems & Climate smart functions & Applicable regions \\
\hline Cropland agroforestry & $\begin{array}{l}\text { Increase } \\
\begin{array}{l}\text { resilience } \\
\text { hailstorms } \\
\text { sequestration }\end{array}\end{array}$ & $\begin{array}{l}\text { Northern, northwestern and } \\
\text { southern region }\end{array}$ \\
\hline $\begin{array}{l}\text { Multistoried agroforestry } \\
\text { systems }\end{array}$ & $\begin{array}{l}\text { Carbon sequestration and } \\
\text { conserving agro-diversity }\end{array}$ & $\begin{array}{l}\text { Upland of Madhupur and } \\
\text { Barind tracts as well as in } \\
\text { homesteads }\end{array}$ \\
\hline Horti-silvicultural system & $\begin{array}{l}\text { Carbon sequestration and } \\
\text { mitigation }\end{array}$ & Coastal and hilly areas \\
\hline $\begin{array}{l}\text { Use of live barriers in crop field } \\
\text { (live fencing, Shelterbelt and } \\
\text { wind break) }\end{array}$ & $\begin{array}{l}\text { Increase resilience to } \\
\text { norwester and cyclone }\end{array}$ & $\begin{array}{l}\text { Southern coastal and tornado } \\
\text { prone regions }\end{array}$ \\
\hline $\begin{array}{l}\text { Agri-horti-silvicultural (mixed } \\
\text { agroforestry instead of shifting } \\
\text { cultivation) }\end{array}$ & $\begin{array}{l}\text { Soil erosion control, prevent } \\
\text { landslides and } \\
\text { sequestration }\end{array}$ & $\begin{array}{l}\text { Hilly area of north and south- } \\
\text { eastern region }\end{array}$ \\
\hline Planting crops in tree stands & $\begin{array}{l}\text { Carbon sequestration and } \\
\text { mitigation }\end{array}$ & Throughout the country \\
\hline Aquaforestry & $\begin{array}{l}\text { Carbon sequestration and } \\
\text { mitigation }\end{array}$ & $\begin{array}{l}\text { Throughout the country } \\
\text { specially in southern coastal } \\
\text { belt }\end{array}$ \\
\hline
\end{tabular}

\section{Conclusions}

Climate change is one of the greatest challenges for agricultural production and food security now. Therefore, farmers should adopt climate smart agricultural practices like agroforestry, in order to address the climate change impacts on food security. Agroforestry is one of the most promising components of a climate smart agriculture toolbox due to its high potential for sustainably increasing agricultural production, building resilience to climate change, sequestering carbon, and strengthening farmers' income and livelihoods. Hence, the promotion of the adoption/adaptation of agroforestry practices is highly important to increase the resiliency to future climate change in Bangladesh. Based on these facts, a few recommendations can therefore be suggested: More quantitative research on carbon sequestration potentials of different agroforestry systems should be conducted by the researchers. The agricultural extension department of the government should execute more extension programs and campaigns on CSA to increase awareness among farmers to promote the adoption of agroforestry as CSA technology.

\section{References}

Billah, M.M. and Hossain, M.A. 2017. Role of climate smart agriculture technologies in sustainable crop production by the coastal farmers of Bangladesh. Imperial $J$. Interdiscipl. Res. 3(10): 398-403.

CGIAR. 2017. Agriculture's prominence in the INDCs: data and maps, Research program on climate change, agriculture and food security (CCAFS). https://ccafs.cgiar.org/agriculturesprominence-indcs-data-andmaps\#.XvyWrCgzbIV
Colin, M. 2013. Agroforestry and Smallholder Farmers: climate change adaptation through sustainable land use. Capstone Collection, Paper 2612. pp. 1-40.

Cubbage, F., Balmelli, G., Bussoni, A., Noellemeyer, E., Pachas, A.N., Fassola, H., Colcombet, L., Rossner, B., Frey, G., Dube, F., de Silva, M.L., Stevenson, H., Hamilton, J. and Hubbard, W. 2013. Comparing silvopastoral systems and prospects in eight regions of the world. Agrofor. Syst. 86(3): 303-314.

https://doi.org/10.1007/s10457-012-9582-z

Dastagir, M.R. 2015. Modeling recent climate change induced extreme events in Bangladesh: a review. Weather and Climate Extremes. 7: 49-60.

https://doi.org/10.1016/j.wace.2014.10.003

De Zoysa, M. and Inoue, M. 2014. Climate change impacts, agroforestry adaptation and policy environment in Sri Lanka. Open J. Forest. 4: 439-456.

https://doi.org/10.4236/ojf.2014.45049

Dhyani, S.K., Asha, R., Newaj, R., Handa, A.K. and Dev, I. 2020. Agroforestry for carbon sequestration in tropical India. In: $\mathrm{P}$. Ghosh, et al. (Eds), Carbon Management in Tropical and Sub-Tropical Terrestrial Systems. Springer Nature Singapore Pte Ltd. pp. 313-331.

https://doi:10.1007/978-981-13-9628-1_19

Dollinger, J. and Jose, S. 2018. Agroforestry for soil health. Agrofor. Syst. 92(2): 213-219. https://doi.org/10.1007/s10457-018-0223-9

Elahi, F. and Khan, N.I. 2015. A study on the effects of global warming in Bangladesh. Int. J. Environ. Monitor. Anal. 3(3): 118-122. https://doi.org/10.11648/j.ijema.20150303.12 
FAO. 2010. Climate-smart agriculture: policies, practices and financing for food security, adaptation and mitigation. Food and Agriculture Organization. Rome, Italy. 41p.

Ghosh, P.K., Mahanta, S.K., Mandal, D., Mandal, B. and Ramakrishnan, S. 2020. Carbon Management in Tropical and Sub-Tropical Terrestrial Systems. Springer Nature Singapore Pte Ltd. 438p. https://doi.org/10.1007/978-981-13-9628-1

Goswami, S., Verma, K.S. and Kaushal, R. 2014. Biomass and carbon sequestration in different agroforestry systems of a Western Himalayan watershed. Biol. Agric. Hort. 30(2): 88-96.

https://doi.org/10.1080/01448765.2013.855990

Gurung, T.R. and Temphel, K.J. 2015. Technological advancement in agroforestry systems: Strategy for climate smart agricultural technologies in SAARC Region. Dhaka: Natundhara Printing Press. 294p.

Hanif, M.A., Bari, M.S. and Rahman, A. 2015. Potentiality of carbon sequestration by agroforestry species in Bangladesh. Res. Crops. 16(3): 562-567.

https://doi.org/10.5958/2348-7542.2015.00080.7

Hanif, M.A., Roy, R.M., Bari, M.S., Ray, P.C., Rahman, M.S. and Hasan, M.F. 2018. Livelihood improvements through agroforestry: evidence from northern Bangladesh. Small-scale Forest. 17(4): 505522. https://doi.org/10.1007/s11842-018-9400-y

Hoque, M.Z. and Haque, M.E. 2016. Impact of climate change on crop production and adaptation practices in coastal saline areas of Bangladesh. Int. J. Appl. Res. 2(1): 10-19.

Hossain, J., Ahmed, T., Hasnat, M.Z. and Karim, D. 2014. Screening of tomato varieties for fruit tree-based agroforestry system. Int. J. Agril. Res. Innov. Tech. 4(2): 61-69.

https://doi.org/10.3329/ijarit.v4i2.22652

Hossain, M.I., Riyadh, Z.A., Ferdousi, J., Rahman, M.A. and Saha, S.R. 2020. Crop agriculture of Chittagong Hill Tracts: reviewing its management, performance, vulnerability and development model. Int. J. Agric. Environ. Res. 6(5): 707-727. https://doi.org/10.51193/IJAER.2020.6505

IPCC. 200o. Special report on land use, land use change and forestry. Summary for Policy Makers. Intergovernmental Panel on Climate Change, Geneva, Switzerland. 375p.

IPCC. 2014. Climate change 2014: Impacts, adaptation, and vulnerability. Contribution of Working Group II to the Fifth Assessment Report of the Intergovernmental Panel on Climate Change. Geneva, Switzerland. 32p.

Jose, S. 2009. Agroforestry for ecosystem services and environmental benefits: an overview. Agrofor. Syst. 76(1): 1-10.

https://doi.org/10.1007/s10457-009-9229-7
Kabir, M.E. and Webb, E.L. 2008. Can Home garden conserve Biodiversity in Bangladesh? Biotropica. 40(1): 95-103.

https://doi.org/10.1111/j.1744-7429.2007.00346.x

Khisa, S.K. 2001. Contour hedgerow intercropping agroforestry technology for degraded hillside farms in Chittagong hill tracts. pp. 179-184. In: Proceedings of the National Workshop on "Agroforestry Research and Development in Bangladesh", BARI, Gazipur.

Kreft, S., Eckstein, D. and Melchior, I. 2017. Global climate risk index 2017: who suffers most from extreme weather events? Weatherrelated loss events in 2015 and 1996 to 2015 . 32p.

https://germanwatch.org/sites/germanwatch.org/ files/publication/16411.pdf

Lorenz, K. and Lal, R. 2014. Soil organic carbon sequestration in agroforestry systems. A review. Agro. Sustain. Develop. 34(2): 443454. https://doi.org/10.1007/s13593-014-0212-y

Luedeling, E., Sileshi, G., Beedy, T.D. and Dietz, J. 2011. Carbon sequestration potential of agroforestry systems in Africa. In: Kumar, B.M. and Nair, P.K.R. (Eds), Carbon Sequestration Potential of Agroforestry Systems: Opportunities and Challenges. Springer Dordrecht Heidelberg London New York. pp. 61-83.

https://doi.org/1007/978-94-007-1630-8_4

Mahashin, M. and Roy, R. 2017. Mapping Practices and Technologies of Climate Smart Agriculture in Bangladesh. J. Environ. Sci. Nat. Resour. 10(2): 29-37.

Mandal, S. 2016. Climate is changing: food and agriculture must too: A key note paper presented in the seminar "World Food Day 2016" on $16^{\text {th }}$ October 2016, organized by Ministry of Agriculture, Bangladesh. 17p.

Miah, M.G., Islam, M.M., Rahman, M.A., Ahamed, T., Islam, M.R. and Jose, S. 2018. Transformation of jackfruit (Artocarpus heterophyllus Lam.) orchard into multistory agroforestry increases system productivity. Agrofor. Syst. 92(6): 16871697. https://doi.org/10.1007/s10457-017-0118-1

Minar, M.H., Hossain, M.B. and Shamsuddin, M.D. 2013. Climate change and coastal zone of Bangladesh: vulnerability, resilience and adaptability. Middle-East J. Sci. Res. 13(1): 114-120.

https://doi.org/10.5829/idosi.mejsr.2013.13.1.64121

Mukul, S.A. 2014. Biodiversity conservation and ecosystem functions of traditional agroforestry systems: case study from three tribal communities in and around Lawachara National Park. pp. 171-179. In: Chowdhury, M.S.H. (Eds), Forest conservation in protected areas of Bangladesh. Springer International Publishing Switzerland. https://doi.org/10.1007/978-3-319-08147-2_8 
Murthy, I.K., Gupta, M., Tomar, S., Munsi, M., Tiwari R., Hegde, G.T. and Ravindranath, N.H. 2013. Carbon sequestration potential of agroforestry systems in India. J. Earth Sci. Climatic Change. 4(1): 1-7.

https://doi.org/10.4172/2157-7617.1000131

Mutahara, M., Warner, J.F., Wals, A.E.J., Khan, M.S.A. and Wester, P. 2017. Social learning for adaptive delta management: tidal river management in the Bangladesh delta. Int. J. Water Resour. Develop. 34(6): 923-943. https://doi.org/10.1080/07900627.2017.1326880

Newaj, R. and Dhyani, S.K. 2008. Agroforestry for carbon sequestration: scope and present status. Indian J. Agrofor. 10: 1-9.

Newaj, R., Chavan, S.B. and Prasad, R. 2015. Climate-smart agriculture with special reference to agroforestry. Indian J. Agrofor. 17(1): 96-108.

Newaj, R., Rizvi, R.H., Chaturvedi, O.P., Alam, B., Prasad, R., Kumar, D. and Handa, A.K. 2017. A country level assessment of area under agroforestry and its carbon sequestration potential. Technical bulletin 2/2017, Central Agroforestry Research Institute, Jhansi. pp. 1-48.

Pal, B.D., Joshi, P.K. and Tyagi, N.K. 2019. Twoway association between agriculture and climate change. pp. 1-16. In: Pal, et al. (Eds), Climate Smart Agriculture in South Asia. Singapore: Springer Nature Singapore Pte Ltd.

https://doi.org/10.1007/978-981-10-8171-2_1

Peichl, M., Thevathasan, N.V., Gordon, A.M., Huss, J. and Abohassan, R.A. 2006. Carbon sequestration potentials in temperate treebased intercropping systems, Southern Ontario, Canada. Agrofor. Syst. 66(3): 243257. https://doi.org/10.1007/s10457-005-0361-8

Possu, W.B., Brandle, J.R., Domke, G.M., Schoeneberger, M. and Blankenship, E. 2016. Estimating carbon storage in windbreak trees on U.S. agricultural lands. Agrofor. Syst. 90: 889-904. https://doi.org/10.1007/s10457-0169896-0

Rahaman, M.A., Rahman, M.M. and Hossain, M.S. 2019. Climate-resilient agricultural practices in different agro-ecological zones of Bangladesh. In: Filho, W.L. (Ed.), Handbook of Climate Change Resilience. pp. 1-27. Springer Nature Switzerland. https://doi.org/10.1007/978-3-319-71025-9_42-1

Rahman, A., Mojid, M.A. and Banu, S. 2018. Climate change impact assessment on three major crops in the north-central region of Bangladesh using DSSAT. Int. J. Agril. Biol. Engi. 11(4): 135-143.

https://doi.org/10.25165/j.ijabe.20181103.3331

Rahman, M.A., Miah, M.G. and Yahata, H. 2009. Maize production and soil properties change in alley cropping system at different nitrogen levels. The Agriculturists. 7(1-2): 41-49.
Raj, A., Jhariya, M.K. and Bargali, S.S. 2018. Climate smart agriculture and carbon sequestration. pp. 1-19. In: Pandey, et al. (Eds), Climate Change and Agroforestry. New India Publishing Agency. New Delhi, India.

Richards, M., Bruum, T.B., Campbell, B.M., Gregersen, L.E., Huyer, S., Kuntze, V., Madsen, S.T.N., Oldvig, M.B. and Vasileiou, I. 2016. How countries plan to address agricultural adaptation and mitigation: an analysis of Intended Nationally Determined Contributions. CCAFS dataset version 1.2 Copenhagen, Denmark: CGIAR Research program on Climate Change, Agriculture and Food Security (CCAFS). pp. 1-8.

Rietveld, W.J. 1995. Agroforestry: a maverick science and practice. Proceedings of Agroforestry and Sustainable Systems Symposium of USDA. 9p.

Rijal, S. 2019. Agroforestry System: approaches for climate change mitigation and adaptation. Acta Scient. Agric. 3(9): 140-142. https://doi.org/10.31080/ASAG.2019.03.0621

Riyadh, Z.A., Rahman, M.A., Miah, M.G., Saha, S.R., Hoque, M.A., Rahman, M.M. and Miyajima, I. 2020. Performance of Spices as Lower-Storey Crop in Jackfruit-Papaya Multistorey Agroforestry System in Bangladesh. J. Fac. Agric. Kyushu Univ. 65(2): 223-231.

https://doi.org/10.5109/4103694

Riyadh, Z.A., Rahman, M.A., Saha, S.R. and Hossain, M.I. 2018. Soil properties under jackfruit-based agroforestry systems in madhupur tract of Narsingdi district. $J$. Sylhet Agril. Univ. 5(2): 173-179.

Saikia, P., Kumar, A. and Khan. M.L. 2017. Agroforestry: a sustainable land use system for livelihood security and climate change mitigation. pp. 61-70. In: Pandey, et al. (Eds), Climate Change and Agroforestry. New India Publishing Agency. New Delhi, India.

Schoreneberger, M., Bendrub, G., Gooijer, H., Soolanayakanahal, R., Sauer, T., Brandle, J., Zhan, X. and Cuer, D. 2012. Branching out: agroforestry as a climate change mitigation and adaptation for agriculture. J. Soil Water Conserv. 67(5): 128-136.

https://doi.org/10.2489/jswc.67.5.128A

Sikder, R. and Xiaoying, J. 2014. Climate change impact and agriculture of Bangladesh. $J$. Environ. Earth Sci. 4(1): 35-40.

Smith, P. and Olesen, J.E. 2010. Synergies between the mitigation of, and adaptation to, climate change in agriculture. J. Agril. Sci. 148: $543-552$. https://doi.org/10.1017/Soo21859610000341

Srinivasarao, C. 2017. Carbon sequestration and climate smart agriculture. pp. 91-95. In: Belavadi et al. (Eds), Agriculture under climate change. Allied Publishers Pvt. Ltd. New Delhi, India. 
Srinivasarao, C., Sharma, K.L. and Kundu, S. 2020. Potential soil carbon sequestration in different land use and management systems in peninsular India. pp. 3-21. In: P. Ghosh, et al. (Eds), Carbon Management in Tropical and Sub-Tropical Terrestrial Systems. Springer Nature Singapore Pte Ltd.

https://doi.org/10.1007/978-981-13-9628-1_1

Talukder, M.S., Miah, M.M.U., Miah, M.G., Haque, M.M., Rahman, M.M. and Islam, M.M. 2019. Fruit tree-based agroforestry systems and their carbon sequestration potentials in different ecosystem of Bangladesh. J. Agrofor. Environ. 13(1\&2): 43-48.

Trisurat, Y., Alkemade, J.R.M. and Arets, E.J.M.M. 2009. Projecting forest tree distributions and adaptation to climate change in northern Thailand. J. Ecol. Nat. Environ. 1(3): 55-63.

UNFAO. 2014. Knowledge on climate smart agriculture, United Nations Food and Agriculture Organization (UNFAO) research program on climate change, agriculture and food security (CCAFS).

https://cgspace.cgiar.org/bitstream/handle/10568 /42432/About\%20CSA_Q\%26A.pdf?sequence=1

UNFCCC. 2010. Handbook for Conducting Technology Needs Assessment for Climate Change. United Nations Framework Convention on Climate Change, Bonn, Germany. 165p.

Uthappa, A.R., Chavan, S.B., Dhyani, S., Handa, A.K. and Newaj, R. 2015. Trees for soil heath and sustainable agriculture. Indian Far. 65: 2-5.

Uthappa, A.R., Chavan, S.B., Handa, A.K., Newaj, R., Kumar, D., Sridhar, K.B. and Chaturvedi, O.P. 2017. Agroforestry - a sustainable solution to address climate change challenges. pp. 1-22. In: Gupta, et al. (Eds), Agroforestry for Increased Production and Livelihood Security, New India Publishing Agency. New Delhi.

Verchot, L.V., Noordwijk, M.V., Kandji, S., Tomich, T., Ong, C., Albrecht, A., Mackensen, J., Bantilan, C., Anupama, K.V. and Palm, C. 2007. Climate change: linking adaptation and mitigation through agroforestry. Mitig. Adapt. Strat. Glob. Chang. 12(5): 901-918. https://doi.org/10.1007/s11027-007-9105-6

Verma, A., Kaushal, R., Alam, N.M., Mehta, H., Chaturvedi, O.P., Mandal, D., Tomar, J.M.S., Rathore, A.C. and Singh, C. 2014. Predictive models for biomass and carbon stocks estimation in Grewia optiva on degraded lands in western Himalaya. Agrofor. Syst. 88(5): 895-905.

https://doi.org/10.1007/s10457-014-9734-1

Wekesa, B.M., Ayuya, O.I. and Lagat. J.K. 2018. Effect of climate-smart agricultural practices on household food security in smallholder production systems: Micro-level evidence from Kenya. Agric. Food Sec. 7(1): 1-14. https://doi.org/10.1186/s40066-018-0230-0

World Bank. 2006. Unlocking opportunities for forest-dependent people in India. New Delhi, India: The World Bank Agriculture and Rural Development Sector Unit, South Asia Region. $107 \mathrm{p}$.

http://siteresources.worldbank.org/INDIAEXTN/ Resources/Reports-Publications/3663871143196617295/Forestry_Report_volume_I.pdf

World Bank. 2017. Climate-smart agriculture in Bangladesh, CSA country profiles for Asia series. International Center for Tropical Agriculture (CIAT), World Bank. Washington, D.C. 28p. 